\title{
Kínában elkészült az AG-600-as, a világ második legnagyobb amfíbiája
}

2 016. július 24-én szűkszavú kínai bejelentés közölte, hogy előző nap a dél-kínai Kuangtung tartomány Zuhaj nevű tengerparti városában legördült a gyártósorról a Kínai Repülőgépipari Egyesülés (Aviation Industry Corporation of China) AG-600-as amfíbia első példánya.

A gépet szokásos gyári ünnepség keretében adták át, egyelőre az alapozó sárga színben, nyilván a feladat kijelölése után kap végleges kamuflázst.

A hagyományos repülőgépekhez hasonló szárazföldi bevetéseken túl, képes olyan vízterületekről felszállni és olyanokra leszállni, amelyek legalább 1500 m hosszúak, 200 m szélesek és 2,5 m mélyek.

A szakemberek dicsérik kiváló manőverező képességét, viszonylag nagy kutatási hatókörét és megjegyzik: távoli tengeri területekről akár 50 ember egyidejű mentésére, szállítására képes. Az elsősorban vészhelyzetekre konstruált légi jármű tűzoltó feladatok során 12 t vizet tud befogadni $20 \mathrm{sec}$ alatt és akár 37 t víz szállítására képes teli üzemanyag-tartállyal.

„Az AG-600-as olyan, mint egy hajó, amelyik repülni is tud" - állapította meg Huang Ling-caj, a repülőgép vezető tervezőmérnöke a Hszinhua hírügynökségnek.

Az AG-600-as hét év kutatómunkájának eredménye; 70 repülőgépalkatrész-gyártó, több kutatócsoport és 20 tartomány, illetve város több mint 150 intézete dolgozott rajta. A fejlesztéshez és gyártáshoz szükséges engedélyeket 2009-ben adták meg.

Ezzel Kína elkészítette a világ egyik legnagyobb kétéltű repülőgépét, amelyet elsősorban erdőtüzek oltásához és tengeri mentéshez kívánnak majd használni (legalábbis a mostani közlés szerint). Az új gigászi AG-600-as amfíbia sorozatgyártását már évekkel korábbra tervezték, de első példánya csak 2016. július 23-án gördült le a gyártósorról. Az eseményt a repülési szakemberek mérföldkőnek tekintik az ország repülőgépiparában.

Az AG-600-as (amelyet korábban JL 600-asként is emlegettek) maximális felszálló tömege 53,5 t, utazósebessége $500 \mathrm{~km} / \mathrm{h}$, 12 órán át tartható folyamatosan használatban. A mintegy 37 m hosszú amfíbia - 38,8 m szárnyfesztávolsággal - paramétereit tekintve, nemzetközi összehasonlításban bőven csúcstartó, leginkább egy Boeing 737eshez hasonlítható.

ÖSSZEFOGLALÁS: 2016-ban elkészült a kínai AG-600-as amfíbia első példánya. $A$ kétéltű repülőgép 50 ember szállitására képes, tűzoltó feladatok során pedig 37 t vizet tud befogadni. A $37 \mathrm{~m}$ hosszú amfíbia utazósebessége $500 \mathrm{~km} / \mathrm{h}$, hatótávolsága $5500 \mathrm{~km}$. A törzsön jobb és bal oldalon 1-1 oldalajtó látható. Futómúvét a csónaktestbe vonja be, így betonos repülőtérre történő le- és felszállásra is alkalmas. A kínai haditengerészet akár felderítésre, akár tengerészgyalogság és fegyverzetének szállítására alkalmazhatja.

KULCSSZAVAK: Kína, haditengerészet, amfíbia, tűzoltás, kutató-mentő
A dezinformáció most is jelen van, a közölt nézeti rajz nem a megépült példányt ábrázolja, és a közölt számszerű adatokban is több eltérés van.

A korábbi TA-600-as változat normál vezérsíkos kialakítású, egyéb jellemzőiben azonos az AG-600-assal, csak nem épült meg.

1. táblázat. A TA-600-as és az AG-600-as amfíbiák fő jellemzői

\begin{tabular}{|l|c|c|}
\hline & TA-600 & AG-600 \\
\hline Törzs hossza & $36,9 \mathrm{~m}$ & $37,0 \mathrm{~m}$ \\
\hline Fesztávolság & $38,8 \mathrm{~m}$ & $38,3 \mathrm{~m}$ \\
\hline Magasság & $12,1 \mathrm{~m}$ & $12,0 \mathrm{~m}$ \\
\hline Max. felszálló tömeg & $49000 \mathrm{~kg}$ & $53500 \mathrm{~kg}$ \\
\hline Normál felszálló tömeg & $\begin{array}{c}53500 \mathrm{~kg} \\
\text { (beton) }\end{array}$ & \\
\hline $\begin{array}{l}4900 \mathrm{~kg} \\
(\mathrm{viz} / \mathrm{l})\end{array}$ & n.a. \\
\hline Max. vízfelvétel & $12000 \mathrm{~kg}$ & $16-20000 \mathrm{~kg}$ \\
\hline $\begin{array}{l}\text { Max. sebesség kis } \\
\text { magasságon }\end{array}$ & $560 \mathrm{~km} / \mathrm{h}$ & $500 \mathrm{~km} / \mathrm{h}$ \\
\hline Max. utazó sebesség & $500 \mathrm{~km} / \mathrm{h}$ & n.a. \\
\hline $\begin{array}{l}\text { Min. sebesség kis } \\
\text { magasságon }\end{array}$ & $220 \mathrm{~km} / \mathrm{h}$ & n.a. \\
\hline Hatótávolság & $5500 \mathrm{~km}$ & n.a. \\
\hline $\begin{array}{l}\text { Szolgálati } \\
\text { csúcsmagasság }\end{array}$ & $10500 \mathrm{~m}$ & $6000 \mathrm{~m}$ \\
\hline
\end{tabular}

A kínai Zhuzhou Aero-Engine Factory (ZEF) WJ-6 (Ivchenko Al-20 licensz) gázturbinák 6 tollú propfan légcsavarral vannak ellátva. A hajtómű max. teljesítménye: 3809 kW (felszálláskor), 2004 kW (utazáskor).

ABSTRACT: In 2016, the first Chinese AG-600 amphibious aircraft have been built. It is capable of transporting 50 people and storing $37 \mathrm{t}$ water to execute firefighting missions. Cruising speed of the $37 \mathrm{~m}$ long aircraft is $550 \mathrm{~km} / \mathrm{h}$, its range is $5500 \mathrm{~km}$. On both sides of the fuselage there is a door. Its undercarriage is pulled into a boat-form body so the aircraft is capable of taking of from concrete airport runway and landing on it. The Chinese Navy can use it either for reconnaissance or for transport marine force and their weapons.

KEY WORDS: China, Navy, amphibious aircraft, firefighting, search and rescue 


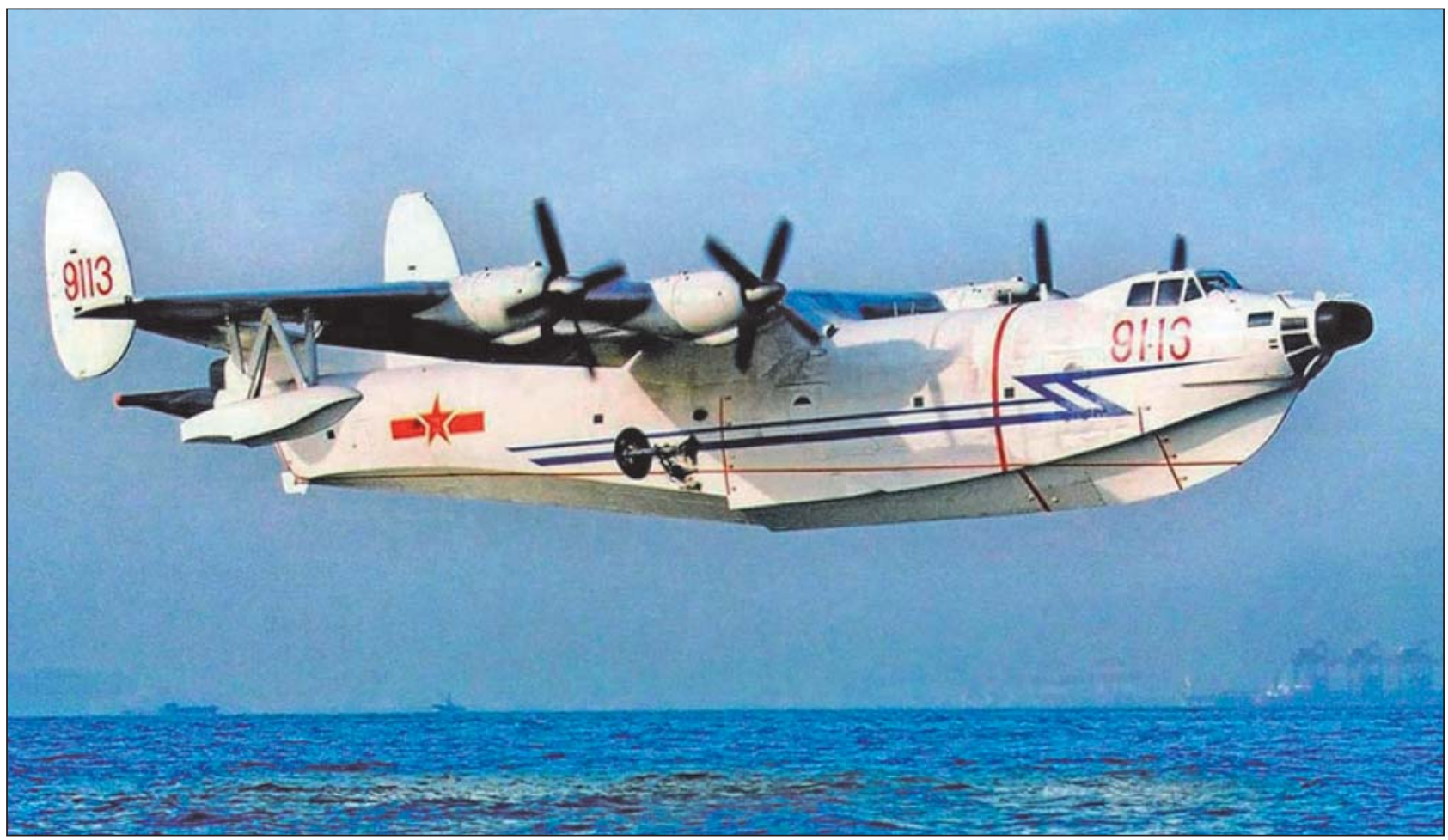

1. ábra. Az 1984-ben épült SH-5-ös egyik példánya

A törzsön jobb és bal oldalon 1-1 oldalajtó látható, a gép farokrészéről nincs jó felvétel, de valószínűleg nem rendelkezik rámpával.

$\mathrm{Az}$ orrkerekes elrendezésű futóművét a csónaktestbe vonja be, minden betonos reptérre történő le és felszállásra alkalmas. A vezérsík magasra emelt „T” kialakítású, ez védi a felvert víztől.

Hasonló kialakításban a japán Shin Meiva PX-S, és a régi amerikai Martin SP-5B típus ismert, de ezek már nincsenek rendszerben és kisebb méretűek is voltak.

A Beriev gyár Be-42 „Albatros” (NATO kód: Mermaid) jelű amfíbiája 1987 áprilisában végezte első felszállását. Ez számított a legnagyobb amfíbiának. Fesztávja 41,62 m, hossza 43,87 m, magassága 11,07 m volt, max. felszállási tömege 86-90 tonna. Ebből irányozták elő Berijev A-40 jellel 20 db sorozatgyártását 1992-re. 1991-ben a Szovjetunió összeomlott, a típus gyártásából végül nem lett

2. ábra. Az AG-600-as amfíbia készre szerelt sárkányát a gyári ünnepségre vontatják

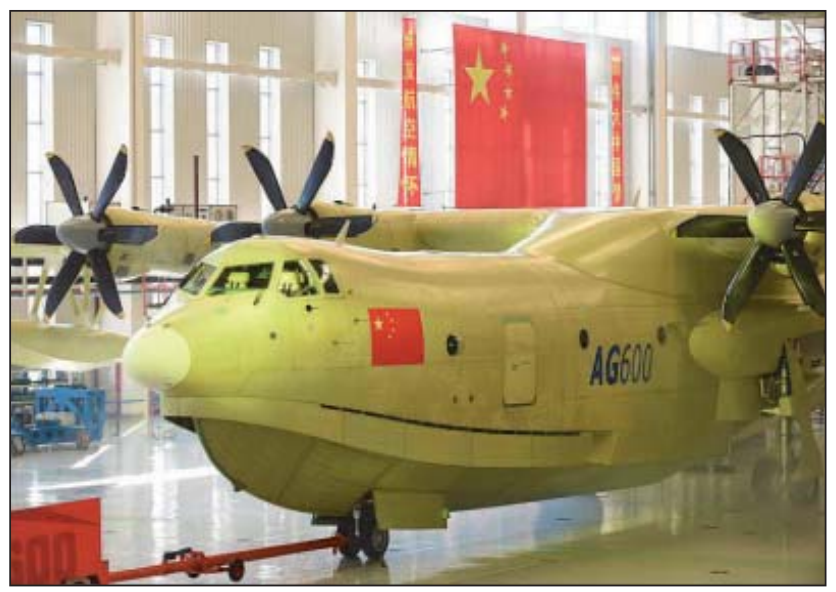

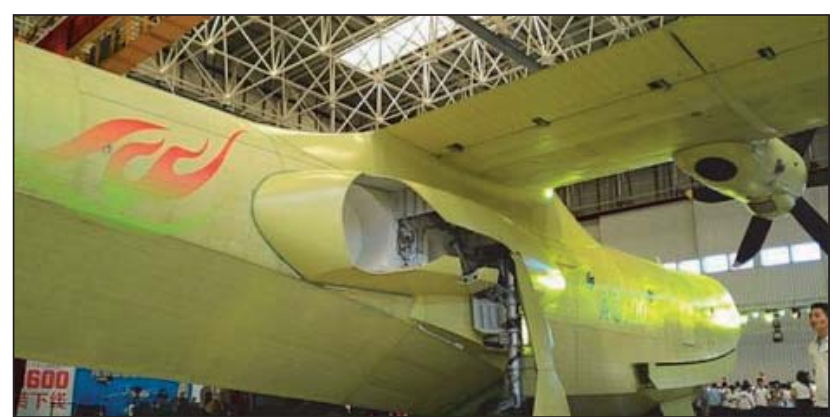

3. ábra. Az egyik hajtómú, a légcsavar, illetve a törzs oldalán kiképzett futómú-akna

semmi. 1997-ben az orosz haditengerészet légiereje végleg lemondott a katonai változatról.

2002-től a Taganrogban lévő gyár megkezdte az áttervezett, kisebb Be-200-as „Altair” jelű polgári változat gyártását. Ebből 4 változatban $3 \mathrm{db}$ prototípus és $15 \mathrm{db}$ szériagép épült meg, ezek max. $12 \mathrm{t}$ vizet vehetnek fel, a repülő tömeg max. 37,2 t lehet. Ennek fesztávja 32,8 m; hossza $32 \mathrm{~m}$; magassága 8,9 m, tehát kisebb, mint a kínai típus.

A „legnagyobb” jelző csak a Beriev A-42-es egy darab prototípusára igaz, mely a Beriev A-40-es továbbfejlesztett változata.

\section{4. ábra. A törzsszekciók összerakása}

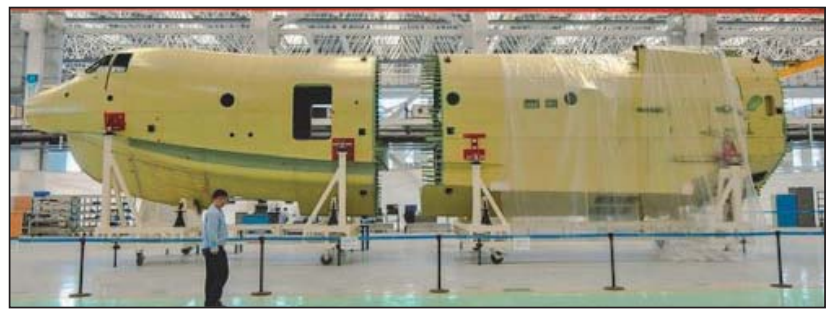




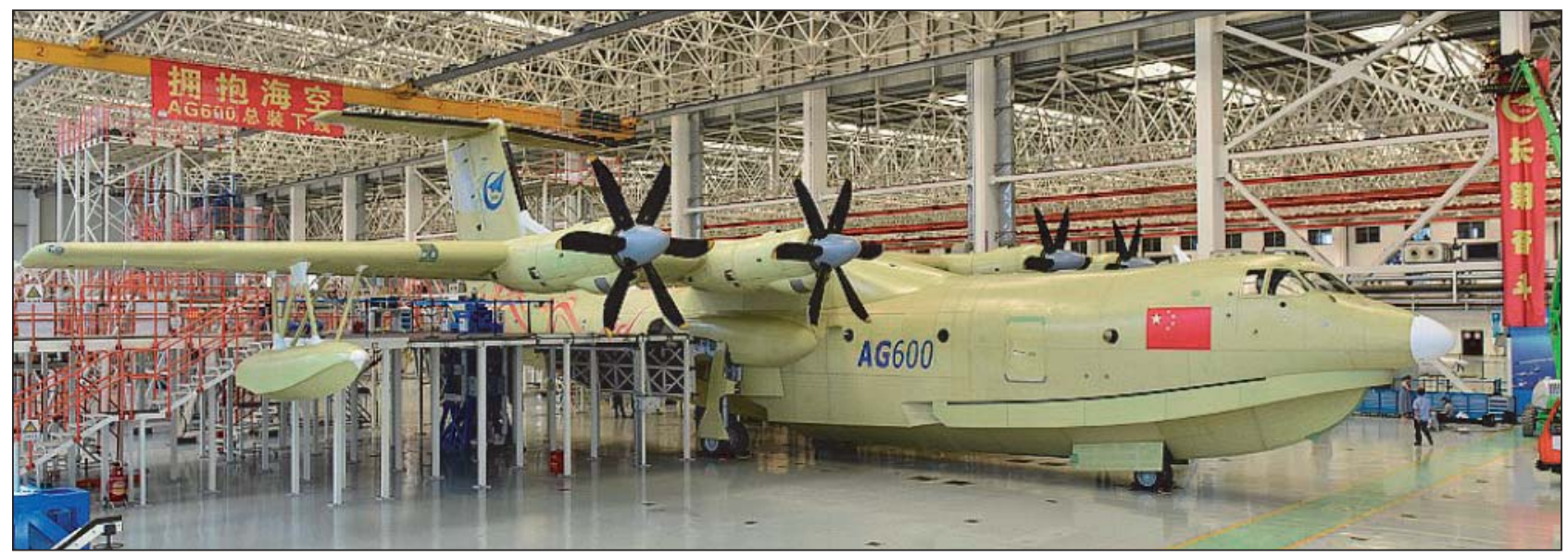

5. ábra. Jól láthatók a stabilitásért felelős segédúszók

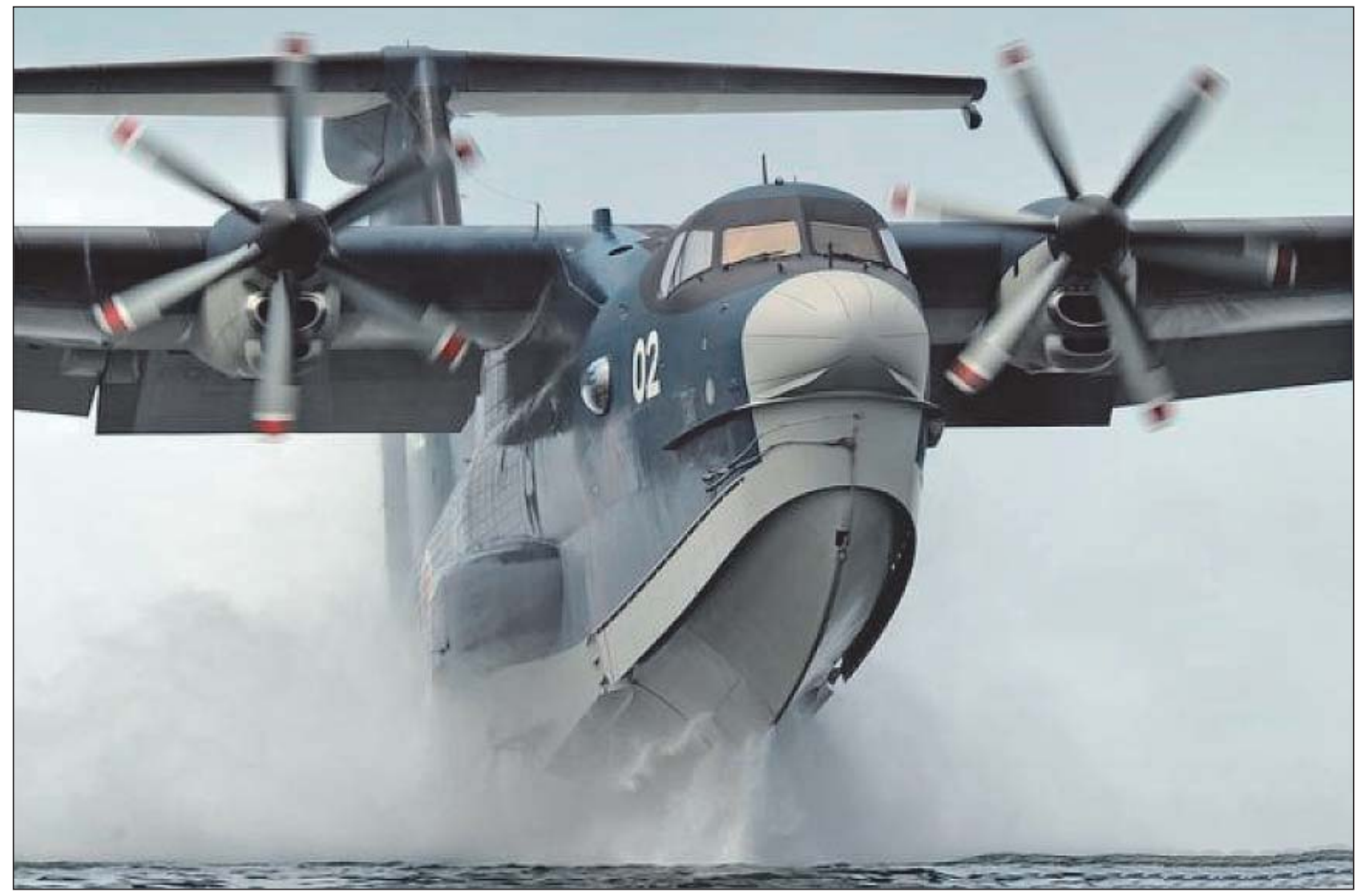

6. ábra. Az AG-600-as amfíbia 02-es számú prototípusának felszállása a tengerről, már haditengerészeti színekben, 2017 elején

A kínai előzmény sem volt kicsi. A Harbin Aircraft Manu₹- facturing Corporation (HAMC) SH-5-ös amfíbia 1976-ban épült meg 4 db Dongan WJ-5-ös hajtóművel. 1984-85-ben ¿ $7 \mathrm{db}$ épült, csak a kínai haditengerészet légiereje használ¿ ta. Ennek fesztávja $36,0 \mathrm{~m}$, hossza $38,9 \mathrm{~m}$, magassága 9,79 m, max. felszálló tömege elérte a 45 tonnát. Kínai források szerint összesen $7 \mathrm{db}$ SH-5-ös készült: $3 \mathrm{SH}-5 \mathrm{X}$ Prototípus, $3 \mathrm{db} \mathrm{SH}-5 \mathrm{~A}$ tengeri járőr (Maritime Patrol Aircraft - MPA) és $1 \mathrm{db}$ SH-B tűzoltó. Az osztott vezérsíkos gép főleg ASW (Anti-submarine warfare - tengeralattjáró elleni hadviselés) feladatkörben repült, de csónakteste jelentősen hasonlít az AG-600-ashoz. A bevált megoldásokat nyilvánvalóan átvették, a kutatás-fejlesztés nagy részét

ehhez a típushoz végezték el. Ez 4 db 3150 LE-s Dongan WJ-5-ös gázturbinával és 4 tollú légcsavarokkal repült. A meghajtórendszere azonos az Y-7 jelű teherszállító gépével (ez az An-12-es kínai változata), illetve az Y-8-as, Y-8C, Y-8Q változatokkal.

Jelenleg csak annyi ismeretes, hogy az AG-600-ast elsősorban hazai igényekre szánják, tűzoltó és tengeri mentési célra. Eddig 17 darabra jelentettek be igényt, ezek polgári változatok.

A haditengerészet nehézség nélkül alkalmazhatja katonai, fegyveres változatát, akár felderítésre, akár tengerészgyalogság és fegyverzetének szálítására. Katonai igényekről adat nem ismeretes. 